\title{
Knowledge, Attitudes and Practices on Community with Dengue Haemorrhagic Fever in Mataram, West Nusa Tenggara
}

\author{
Pengetahuan, Sikap dan Praktik Masyarakat dengan Demam Berdarah Dengue di \\ Mataram, Nusa Tenggara Barat
}

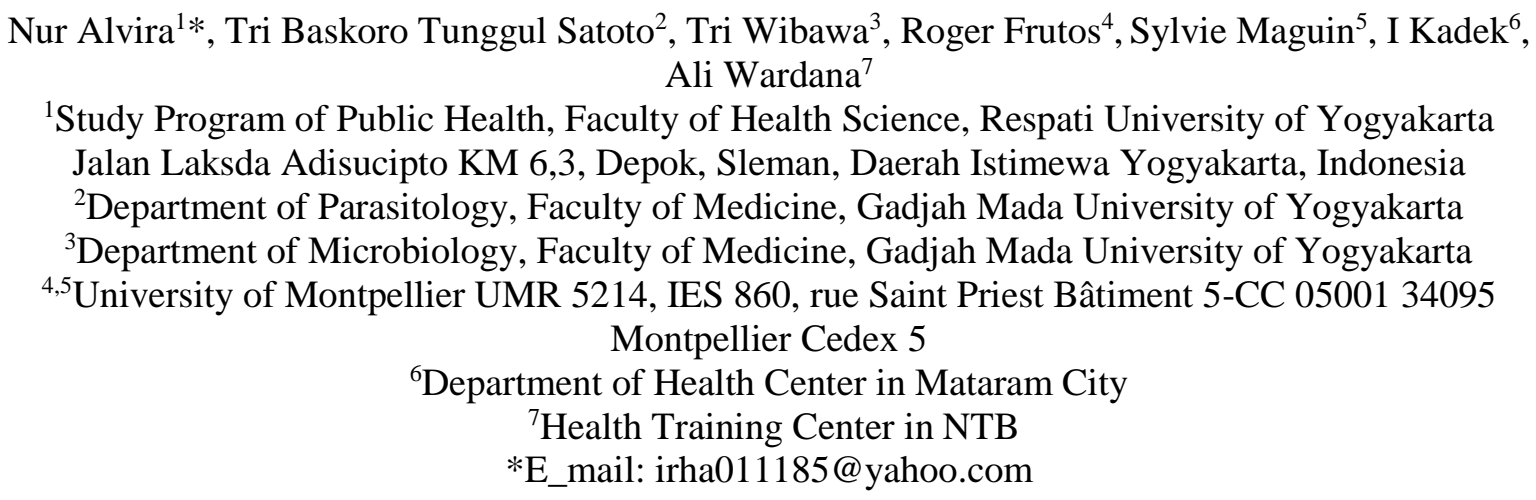

Received date: 03-05-2020, Revised date: 11-09-2020, Accepted date: 11-11-2020

\begin{abstract}
Dengue Haemorrhagic Fever (DHF) is a major health problem in Mataram. Even though there have been many prevention efforts, the rates of morbidity and mortality tend to increase. This condition shows that the indicators of Knowledge, Attitude, and Practice (KAP) about DHF in the community are still low. This study aims to prove the factors KAP in the community with DHF in Mataram City. The research conducted in October-November 2018 used a case-control study. The sampling technique used proportional stratified random sampling. The KAP data were collected by interview using questionnaires and observation using a structured checklist. Data analysis used a simple and multiple logistic regression test $(\alpha=5 \%)$. Factors related to DHF transmission in Mataram are the communities' habit of raising livestock, does not have a temporary landfill, low knowledge about DHF, lots of garbage around the house and the determinant factor is a routine mobilization to endemic areas $(\mathrm{OR}=$ 17.019). DHF reduction in Mataram City can be carried out through integrated cross-sectoral vector control activities as through waste management; build livestock pens according to health standards and provide education, especially for community living in endemic areas.
\end{abstract}

Keywords: mobilization, waste, livestock, knowledge, Dengue Haemorrhagic Fever

\begin{abstract}
ABSTRAK
Demam Berdarah Dengue (DBD) masih menjadi penyakit endemik di Kota Mataram. Meskipun telah banyak upaya pencegahan dilakukan, namun jumlah kasus dan kematian cenderung meningkat. Kondisi ini menunjukkan bahwa indikator Pengetahuan, Sikap, Praktik (PSP) tentang DBD pada masyarakat masih rendah. Penelitian ini bertujuan untuk membuktikan faktor PSP pada masyarakat dengan DBD di Kota Mataram. Penelitian yang dilaksanakan pada Bulan Oktober-November 2018 menggunakan studi kasus kontrol. Teknik pengambilan sampel menggunakan proportional stratified random sampling. Data PSP diperoleh dari interview menggunakan kuesioner dan observasi dilakukan dengan menggunakan form observasi terstruktur. Analisis data menggunakan uji regresi logistik sederhana dan berganda $(\alpha=5 \%)$. Faktor yang berhubungan dengan penularan DBD di Mataram adalah kebiasaan masyarakat memelihara ternak, tidak memiliki tempat pembuangan sampah sementara, rendahnya pengetahuan tentang DBD, banyak sampah di sekitar rumah dan faktor determinan adalah mobilisasi rutin ke daerah endemis $(O R=17,019)$. Penurunan kasus DBD di Kota Mataram dapat dilakukan melalui kegiatan pengendalian vektor terpadu lintas sektor seperti pengelolaan sampah, membangun kandang ternak yang sesuai standar kesehatan dan memberikan edukasi terutama untuk masyarakat yang tinggal di daerah endemis.
\end{abstract}

Kata kunci: mobilisasi, sampah, ternak, pengetahuan, Demam Berdarah Dengue 


\section{INTRODUCTION}

Dengue Hemorrhagic Fever (DHF) is recognized in the WHO region namely America (PAHO), Southeast Asia (SEARO), and the Western Pacific (WPRO). ${ }^{1}$ Indonesia ranked first in SEARO in 1990-2015 based on Incidence Rate (IR) and Case Fatality Rate (CFR). ${ }^{2}$ The incidence Rate (IR) in Indonesia in 2016 increased $(77.96 / 100,000$ population) compared to the previous year $(50.83 / 100,000$ population). This rate is still very far from the national target $(<49 / 100,000$ population) and several provinces in Indonesia experienced an outbreak. ${ }^{3}$ The city of Mataram is an endemic area because even though the incidence rate in Mataram is below the national target, the region has experienced an increase of cases up to $95.88 \%$ in the last 2 years (IR 10.68 $/ 100,000$ in 2015 with CFR 0\%, become IR 20.92/100,000 residents with CFR $0.75 \%$ in 2016). ${ }^{4}$

The incidence of DHF occurs due to demographic factors, urbanization, migration, and population mobility caused a significant increase in dengue cases. ${ }^{5,6}$ Other influential factors are climate change, environmental changes, and transmission of DHF cases that indicate spatial and temporal patterns. ${ }^{7}$ Social and economic factors play an important role in the incidence and prevalence of DF and DHF. The results of research conducted in Aceh shows that the level of education, occupation, marital status, income, socio-economic status (SES), and life in the city associated with the level of knowledge. Occupation, SES, and history of DF were associated with attitude. Education, occupation, socioeconomic status, and residence associated with prevention practices. ${ }^{8}$ This condition is also associated with the quality of the urban environment that is unhealthy because of unplanned urbanization well, that's potential for increasing the dengue vector breeding. ${ }^{9}$

Socio-economic and socio-cultural factors that affect the density of Aedes aegypti mosquitoes and transmission of diseases are unhygienic behavior and unhealthy conditions of the house. Long levels of population density and water storage for daily needs have the potential to become a potential place for the breeding of Aedes aegypti, thus increasing the transmission of dengue infection. ${ }^{10}$ The results of research in Cimahi City show that there is a significant relationship between education, economic status, knowledge, facilities, and infrastructure, providing counseling, and larva inspection with the behavior of respondents in eradicating mosquito breeding places. ${ }^{11}$

Several research results indicate that the predictor variables associated with DHF transmission are not homogeneous and unstable. These factors are related to the behavior of people of various races and ethnicities, making it difficult to assume that epidemiological change is a single factor. Shah et.al stated that dengue epidemics over a period of four years (2004-2007) showed that the incidence of dengue fever was mostly among ethnic Malayu, however, the incidence of cases among non-citizens showed a tendency to increase. Although the factors related to ethnicity have high complexity, the analysis of variables related to the specific conditions of a region on vector distribution and the incidence of dengue cases can be a useful tool to produce spatial and temporal data on the preparation of DHF outbreak prevention scenarios. ${ }^{12}$

DHF is a major health problem in Mataram. Even though there have been many prevention efforts, the rates of morbidity and mortality tend to increase during 2014-2016 and the distribution of areas with endemic status is more than $50 \% .{ }^{13}$ Like a coastal area, assimilation of the population due to a large number of migrants from other regions also occurred in Mataram. Sasak became the majority ethnic group of Mataram residents, followed by the Balinese, Bayan, Dompu, Donggo, Bima, Chinese, Malay, and Arabic tribes. $^{14}$ The number of ethnicities can influence the Knowledge, Attitudes, and Practice (KAP) in the community, thus causing problems in efforts to prevent and treatment of DHF. The aim of this research was to explore and identify KAP factors 
related to Community to DHF in Mataram City. Therefore, understanding local KAP is very important to design a DHF prevention strategy that is appropriate to the local context of an area.

\section{METHODS}

This case-control study was conducted in three districts in Mataram City during October-November 2018. The population in this study were all-household at the research location with a sample calculation using the Lemeshow et al. formulas to test the hypothesis of two sample test of proportions (two-sided test). ${ }^{15}$ There were 90 cases and 90 controls with a total sample of 180 households. The sampling technique used was proportional stratified random sampling, with sub-samples of households in three sub-districts namely Pagutan, Pagutan Barat, and Salagalas. Case criteria are patients who have just been diagnosed in the last three months with a list of cases from the medical record data of DHF patients based on the Epidemiological Investigation (PE Form) and the hospital's early warning report (KDRS Form). Control criteria are not sick with DHF, the nearest neighbor of the case with a maximum distance of 100 meters and match the age, sex between controls and cases.

Knowledge, Attitude, and Practice (KAP) data were collected by interview using questionnaires on published research ${ }^{16,17}$ and observation using a structured checklist a total of forty-eight questions. The practice factors including are insecticide use (5 items), mosquito net ( 7 items), mobilization to an endemic area (9 items), temporary trash shelter and cleanliness around the house (5 items), physical control: frequency of water container cleaning, frequency of garbage disposal and frequency of close the container (3 items) larvicidal use (3 items), livestock raising behavior (5 items), and habit of hanging clothes (1 item). Knowledge (5 items) and attitude (5 items) are assessed by answering cause, mode of transmission, symptoms, mosquito bites, re-infection, breeding sites, and practice measures. Knowledge was classified as good when $80 \%$ or more score, moderate when $60-80 \%$ score and low when less than $60 \%$ score. Attitude score was classified using a similar range as for the classification of knowledge. ${ }^{17}$

Univariate analysis is presented in the frequency distribution, percentages, or proportion and was summarized using tables. Bivariate and multivariate analysis using simple and multiple logistic regression tests with the aim of KAP on Community with Dengue Haemorrhagic Fever in Mataram,. The results of simple logistic regression analysis are used to select variables that match the criteria as candidates for the control model of local DHF outbreaks in Mataram City with a p-value less than $0.25{ }^{18}$ The analysis was continued by multiple logistic regression tests with the backward method to find out the predictor variables in the physical environment and vector density associated with DHF transmission, the strength of the relationship between these variables, and the model or formula for predicting dengue transmission in Mataram City. Model quality assessment was carried out to determine the discrimination value based on the Area Under Curve (AUC) with the Receiver Operating Curve (ROC) method, whereas the model calibration using Hosmer and Lemeshow. ${ }^{19}$ This study is part of a study approved for ethics by the Faculty of Health Science, Respati University of Yogyakarta, with Protocol Number: 167.1/UNRIYO/PL/VII/2018 in July 2018.

\section{RESULTS}

Most cases in Mataram City had a history of DHF once $(96.7 \%)$ and 3.3\% twice. patients who are male and female have almost the same proportion, aged 5-11 years old with an education level graduating from elementary school $(25.6 \%)$ and preschoolers (33.3\%), and the majority are ethnic Sasak (61.1\%) and Bali (27.8\%)

Measurement of KAP with DHF incidence including insecticide use, mosquito net, mobilization to endemic area, temporary 
trash shelter, cleanliness around the house, physical control (frequency of water container cleaning, frequency of garbage disposal, and frequency of close the container), larvicidal use, livestock raising behavior, the habit of hanging clothes, knowledge, and perception of DHF (Table 1).

Table 1. Knowledge-Attitude-Practice (KAP) with DHF in Mataram City according to Simple Logistic Regression

\begin{tabular}{|c|c|c|c|c|c|c|c|}
\hline \multirow{3}{*}{ Knowledge-Attitude-Practice (KAP) } & \multicolumn{4}{|c|}{ Frequency } & \multirow{3}{*}{ OR } & \multirow{3}{*}{ CI $95 \%$} & \multirow{3}{*}{ P-Value } \\
\hline & \multicolumn{2}{|c|}{ Case } & \multicolumn{2}{|c|}{ Control } & & & \\
\hline & $\mathrm{n}$ & $\%$ & $\mathrm{n}$ & $\%$ & & & \\
\hline \multicolumn{8}{|l|}{ Insecticide use } \\
\hline Did not use & 42 & 46.7 & 38 & 42.2 & \multirow[t]{2}{*}{1.197} & $0.665-$ & \multirow[t]{2}{*}{0.652} \\
\hline Used & 48 & 53.3 & 52 & 70.0 & & 2.157 & \\
\hline \multicolumn{8}{|l|}{ Mosquito Net } \\
\hline Did not use & 87 & 96.7 & 86 & 95.6 & \multirow[t]{2}{*}{1.349} & $0.293-$ & \multirow[t]{2}{*}{1.000} \\
\hline Used & 3 & 3.3 & 4 & 4.4 & & 6.206 & \\
\hline \multicolumn{8}{|l|}{ Mobilization to endemic areas } \\
\hline Yes & 87 & 96.7 & 60 & 66.7 & \multirow[t]{2}{*}{14.50} & $4.323-$ & \multirow[t]{2}{*}{0.000} \\
\hline No & 3 & 3.3 & 30 & 33.3 & & 49.685 & \\
\hline \multicolumn{8}{|l|}{ Temporary trash shelter } \\
\hline None & 21 & 23.3 & 3 & 3.3 & \multirow[t]{2}{*}{8.826} & $2.528-$ & \multirow[t]{2}{*}{0.000} \\
\hline Present (Indoor and Outdoor) & 69 & 76.7 & 87 & 96.7 & & 30.816 & \\
\hline \multicolumn{8}{|l|}{ Cleanliness around the house } \\
\hline Lots of garbage found & 68 & 75.6 & 40 & 44.4 & \multirow{2}{*}{3.864} & 2.046- & \multirow[t]{2}{*}{0.000} \\
\hline No trash found & 22 & 24.4 & 50 & 55.6 & & 7.295 & \\
\hline \multicolumn{8}{|l|}{$\begin{array}{l}\text { Physical Control (frequency of water } \\
\text { container cleaning, garbage disposal, and }\end{array}$} \\
\hline $\begin{array}{l}\text { close the container) } \\
\text { Once a week }\end{array}$ & 36 & 40.0 & 17 & 18.9 & \multirow[t]{2}{*}{1.431} & $\begin{array}{l}0.795- \\
2.576\end{array}$ & \multirow{2}{*}{0.296} \\
\hline More than one week/none & 54 & 60.0 & 73 & 81.1 & & & \\
\hline \multicolumn{8}{|l|}{ Larvicidal use } \\
\hline Did not use & 64 & 71.1 & 53 & 58.9 & \multirow[t]{2}{*}{1.718} & $0.925-$ & 0.118 \\
\hline Used & 26 & 28.9 & 37 & 41.1 & & 3.194 & \\
\hline Habit of raising livestock & & & & & & & \\
\hline Present & 47 & 52.5 & 12 & 13.3 & 7.105 & $3.406-$ & 0.000 \\
\hline None & 43 & 47.8 & 78 & 86.7 & & 14.819 & \\
\hline Habit of hanging clothes & & & & & & & \\
\hline Yes & 68 & 75.6 & 64 & 71.1 & 1.256 & $0.647-$ & 0.613 \\
\hline No & 22 & 24.4 & 26 & 28.9 & & 2.436 & \\
\hline Knowledge of DHF & & & & & & & \\
\hline Low & 88 & 97.8 & 75 & 83.3 & 8.800 & 1.949- & 0.001 \\
\hline Good & 2 & 2.2 & 15 & 16.7 & & 39.724 & \\
\hline Perception of DHF & & & & & & & \\
\hline Negative $(\leq 0.008)$ & 61 & 67.8 & 34 & 37.8 & 3.465 & $1.875-$ & 0.000 \\
\hline Positive $(\geq 0.009)$ & 29 & 32.2 & 56 & 62.2 & & 6.402 & \\
\hline Total & 90 & 50.0 & 90 & 50.0 & & & \\
\hline
\end{tabular}

The results show that KAP with the incidence of DHF based on p-value < 0.05 ; OR and confidence interval $>1$, are mobilizing in endemic areas $(\mathrm{OR}=14.50)$; there is no temporary trash shelter $(\mathrm{OR}=8.826)$; found lots of garbage in around the house $(\mathrm{OR}=$ $3.864)$; habit of raising livestock $(\mathrm{OR}=7.105)$, low knowledge of DHF (OR = 8.8), negative perceptions of DHF $(\mathrm{OR}=3.465)$. Insignificant variables are the habit of using insecticides, mosquito nets, and hanging clothes, not doing physical control and larvicidal. 
The low level of knowledge and public perception about DHF is a risk factor for DHF transmission. The results of the analysis on the question items indicate that the knowledge and attitudes of the community about mosquito breeding sites are still very low. The community mostly conducts physical control activities on controllable site (CS) type containers, while the public does not know containers with disposable site types, which have the potential to breed larvae. Community understanding that proper mosquito control through fogging causes the community to feel less responsible for carrying out control activities independently in these places.

Multivariate analysis to determine the type of determinant of KAP factors associated with DHF (Table 2). The results of our simple logistic regression revealed the following independent variables with p-values less than 0.25: mobilizing in endemic areas, no temporary trash shelter, found lots of garbage around the house, the habit of raising livestock, low knowledge of DHF, negative perceptions of DHF and not use larvicida.

Table 2. Knowledge-Attitude-Practice (KAP) with DHF in Mataram City according to Multiple Logistic Regression

\begin{tabular}{|c|c|c|c|c|c|}
\hline \multirow{2}{*}{ Variable } & \multirow[t]{2}{*}{ B } & \multirow[t]{2}{*}{ Sig. } & \multirow[t]{2}{*}{$\operatorname{Exp}(B)$} & \multicolumn{2}{|c|}{ 95,0\% C.I.for EXP(B) } \\
\hline & & & & Lower & Upper \\
\hline Mobilization to endemic areas & 2.440 & 0.000 & 17.109 & 3.540 & 82.697 \\
\hline $\begin{array}{l}\text { Does not have a temporary garbage } \\
\text { collection }\end{array}$ & 1.193 & 0.003 & 12.102 & 2.351 & 62.295 \\
\hline $\begin{array}{l}\text { Found lots of garbage in around the } \\
\text { house }\end{array}$ & 1.804 & 0.028 & 3.333 & 1.378 & 42.060 \\
\hline Habit of raising livestock & 2.121 & 0.000 & 16.790 & 5.461 & 51.624 \\
\hline Low knowledge of DHF & 1.163 & 0.048 & 10.622 & 1.018 & 110.797 \\
\hline Negative attitude of DHF & .371 & 0.082 & 2.161 & 0.906 & 5.157 \\
\hline Constant & -6.334 & 0.000 & 0.007 & & \\
\hline
\end{tabular}

Notes: $B=$ Koefisien Beta; Sig.= Signifikansi; $\operatorname{Exp}(\beta)=$ Eksponen Beta

Forward LR multiple logistic regression was applied. Multi-collinearity was check and not found. Found value of Hosmer and Lemeshow $0.085>0.05$ means that the model is able to predict the value of the observation or model is acceptable because it fit with the data observations. Classification table (overall correctly classified percentage $=78.6$, area under the ROC curve $(83.3 \%)$ was applied to check the model fit ${ }^{19}$

The results of the multivariate analysis showed potential factors related to DHF in the community are routine mobilization to endemic areas $(\mathrm{OR}=17.109)$. Based on Exp (B) value and p-value, this factor is reinforced by the community habit of raising livestock $(\mathrm{OR}=16.790)$, does not have a temporary garbage collection $(\mathrm{OR}=12.102)$, low knowledge of DHF (OR = 10.622), and found lots of garbage around the house $(\mathrm{OR}=$ 3.333).

Logistic regression results that can predict the risk of a family experiencing DHF with the equation and probability formula as follows:

Equation $(y)=-6.334+2.440$ (mobilization to endemic areas) +1.193 (don’t have temporary trash shelter) +0.804 (found lots of garbage around the house) +2.121 (Habit of raising livestock) +1.163 (low knowledge of DHF) +0.371 (negative attitude of DHF $=1.387$ 


$$
\begin{aligned}
& \text { Probability }(\mathrm{P})=\frac{1}{\left(1+e^{-y}\right)}=\frac{1}{\left(1+2,7^{-1,387}\right)}=0.799 \times 100=79.86 \% \\
& \text { Notes: } \\
& P=\text { Probability of an event occurring } \\
& \mathrm{e}=\text { Natural number }=2.7 \\
& y=\text { Constanta }
\end{aligned}
$$

This means that a family who has the habit of mobilization to endemic areas, don't have temporary trash shelters, found a lot of garbage around the house, a habit of raising livestock, low knowledge and negative attitudes about DHF have a probability of experiencing DHF of $79.86 \%$.

\section{DISCUSSION}

Most people in the city of Mataram have activities (mobilization) outside the area of residence, especially those who work/study, worship, and work in other areas with endemic status. Hindu religious communities practice worship in temples that are outside the residential area. The average activity outside the residence is carried out once a week with an activity duration of 8 hours/day and uses private vehicles such as motorcycles and cars.

This condition needs to be monitored because dengue disease can be transmitted through population mobility or this disease does not recognize the boundaries of government administrative areas. $^{20}$ DHF transmission usually spreads starting from a source of infection, then following the traffic of the population. The more crowded the traffic, the greater the possibility of dengue disease spreading. ${ }^{21}$ High population mobility generally occurs in urban areas with supporting means of transportation and information. The more crowded the traffic, the greater the possibility of dengue transmission. ${ }^{22}$ This condition according to the results of research in North Sumatra found that travel to endemic areas was associated with dengue infection. ${ }^{17}$ Pongsumpun and Tang used a mathematical model to the the risk of infection to tourists visiting the dengue fever endemic region and found a significant association $(\mathrm{p}<0.05){ }^{23}$

Do not have a temporary trash shelter and found lots of garbage around the house are associated with DHF incidence. The type of waste found, such as plastic bottles, leftovers, used tires, and discarded plastic, which can be habitats place for dengue vector. Most cases have temporary shelters outside the house but in open conditions. A frequency of disposal of garbage of less than once per 5 days was higher in the case group compared with the control. Observations show that around the case house there was a lot of garbage found because the janitors did not manage the garbage disposal system. The control house, which is mostly located in a housing complex, has a janitor who picks up trash regularly. Another factor is a large number of gardens and vacant land near residential areas, so they tend to dispose of garbage in these places and the habit of collecting rubbish in dug pits for several days before being burn or piled up. Poor waste management provides a place for Aedes mosquitoes to breeding. ${ }^{24}$ Similar findings were researched in North Sumatera ${ }^{17}$ and Thailand. ${ }^{25}$ Waste management which is part of the Integrated Vector Management (IVM) strategy is generally one of the interventions in the prevention of DHF which involves the community through the $3 R$ method namely reduce, reuse, and recycle waste. ${ }^{26}$ However, unfortunately, this behavior is still very low, especially in urban communities due to limited land, lack of knowledge, attitudes, availability of information, as well as the less active role of 
cadres, health workers, academics, and nongovernmental organizations.

Low knowledge about vector breeding places will have an impact on the practice of dengue prevention, as actions based on knowledge are more effective than those without knowledge. In this study, low knowledge in the case group was higher than in the control group. Knowledge about preventive measures is the most unknown to the public compared to the knowledge of other DHF. This finding was supported by research in Kamphaeng Phet Province, where they found that increasing knowledge will improve practices to reduce the number of unprotected containers, thus reducing potential vector breeding places. $^{27}$ Increased community knowledge about dengue and prevention measures is needed because better knowledge provides awareness and the ability to practice preventive measures ${ }^{28-30}$ and this can be done if the community is involved in the control program. ${ }^{31}$

Ownership of livestock is relate to the incidence of DHF in Mataram City. The majority of Sasak ethnic work is raising livestock because the son of the Sasak ethnic began to be introduced and given the responsibility of his father to raising livestock in the grazing fields. This condition has an impact on dengue transmission because plentiful livestock can increase the survival and number of mosquitoes. The community built a cage close to the house and less than 10 meters away. Several things, one of which is for livestock safety, cause placement of the cage. In addition, easy access to the maintenance process and the cage cleaning process. Limitations of community-owned land also factored into the cage built close to the house. Livestock kept in close proximity to humans can contribute to the higher transmission, as they attract mosquitoes into areas where they will encounter and feed on human hosts opportunistically. ${ }^{32}$ The parallel approach of insecticide-treated livestock (ITL) and managing the livestock as far from humans as possible is sufficient to reduce malaria. ${ }^{32,33}$ Likewise, in the Macha region in the southern province of Zambia, livestock dramatically decreased the risk of $P$. falciparum infection at the house level, with an increasing distance between livestock such as cats, cattle, dogs, and goats. ${ }^{34}$

The behavior of using insecticides on respondents has not directly prevented DHF. This could be due to the possible source of mosquito vector habitat. Thus, to support the prevention of dengue fever to prevent contact with vectors, in addition to using household insecticides, it is recommended eradicating mosquito nests, which includes physical control. ${ }^{35}$ Prevention of contact with mosquito vectors with household insecticides will be successful if done correctly and with the right dose. Additionally, the respondents also reported that they have been using the same insecticide for over 6 months with the type of insecticide is a pyrethroid. Piretroid class insecticides are chosen because they work quickly in crippling target insects. ${ }^{36,37}$ Prolonged, repeated use of insecticide from the same group may lead to the development of insecticide resistance, ${ }^{38}$ which in turn may explain non-association with DHF occurrence in this study.

Some of the implications of the results of this study can use as a basis for determining the priority of the DHF prevention program in Mataram City. First increasing the integrated and cross-sectoral vector control strategy, especially in areas with endemic conditions, such as transportation and processing of waste that can be used as breeding sites for dengue vectors through the $3 \mathrm{R}$ method, namely reduce, reuse, and recycle waste. In addition, health education is needed for the breeder community regarding the manufacture and maintenance of cattle sheds in accordance with health standards, especially the distance and cleanliness of the stables. Secondly, the knowledge and information about dengue vector breeding sites, especially the type of container that type disposable sites should get the attention and support of the health authorities. 


\section{CONCLUSION}

KAP in the community with DHF in Mataram City are routine mobilization to endemic areas, the habit of raising livestock, does not have a temporary garbage collection, low knowledge of DHF, and found lots of garbage around the house.

\section{RECOMMENDATIONS}

Health Offices in Mataram City and Community Health Centers need to improve integrated vector control strategies and should be implemented across sectors with the community. The form of activities that can be carried out is a collaboration with the Animal Husbandry Office to provide knowledge, attitude, and practice on the community about making livestock pens that qualifies, so it does not become a potential site for the vector Aedes sp. to breed. Collaborate with the Sanitation Department to provide temporary landfills that are routinely transported by cleaners. In addition, it can collaborate with academics and non-governmental organizations to provide skills to the community about $3 R$, namely reduce, reuse, and recycle waste. An education campaign regarding dengue prevention with a more comprehensive strategy for behavioral change based on the communication and behavior impact method (COMBI). For other effective steps, it is important to increase the knowledge, attitude, and practice of the community about dengue prevention especially in endemic areas and since the incidence of dengue demonstrates seasonality and variation, then before mobilizing to endemic areas, people must protect their skin from mosquito bites according to epidemic activity and seasonal patterns. Improving epidemiological surveillance and vector control programs to prevent the transmission of inter-regional.

\section{ACKNOWLEDGMENT}

The authors are deeply grateful for the 2018 Research Grant from the Ministry of
Education and Research of Indonesia Funds No 1667/UN1/DITLIT/DIT-LIT/LT/2018.

Gratitude is direct towards local health volunteers, field surveyors, and laboratory technicians, without them the study would not have been conducted well.

\section{AUTHOR CONTRIBUTIONS}

All Authors conceived of the presented idea in this manuscript. TBT, TW: developed the theory, NAP: Analyzed data and co-wrote the manuscript, TW, RF: Verified the analytical methods, SM: Ensure the observation procedure of research variables, IKM, AW: verify the data. All authors discussed the results and contributed to the final manuscript: NAP, TBTS: wrote the manuscript with support from TW, RF, SM, IKM, AW.

\section{REFERENCES}

1. Brady OJ, Gething PW, Bhatt S, Messina JP, Brownstein JS, Hoen AG, et al. Refining the global spatial limits of dengue virus transmission by evidence-based consensus. PLoS Negleted Tropical Disease. 2012; 6(8): e1760.

https://doi.org/10.1371/journal.pntd.0001760.

2. Bhatt S, Gething PW, Brady OJ, Messina JP, Farlow AW, Moyes CL, et al. The global distribution and burden of dengue. Nature. 2013; 496(7446): 504-7. doi: 10.1038/nature12060. Epub 2013 Apr 7.

3. Ruberto I, Marques E, Burke DS, Panhuis WGV. The availability and consistency of dengue surveillance data provided online by the World Health Organization. PLOS Neglected Tropical Diseases. 2015; 9(4): e0003511.

https://doi.org/10.1371/journal.pntd.0003511.

4. Dinas Kesehatan Kota Mataram. Laporan data surveillance DBD dalam tahun. Mataram: Dinas Kesehatan Kota Mataram; 2015-2016.

5. Wong LP, Shakir SMM., Atefi N, AbuBakar S. Factors affecting dengue prevention practices: nationwide survey of the Malaysian public. PLoS ONE. 2015; 10(4): e0122890. doi: 10.1371/journal.pone.0122890. 
6. Masyeni S, Yohan B, Somia IKA, Myint KSA, Sasmono RT. Dengue infection in international travellers visiting Bali, Indonesia. J Travel Med. 2018; 25(1): tay061. doi: $10.1093 / \mathrm{jtm} /$ tay061 89.

7. Åström C, Rocklöv J, Hales S, Béguin A, Louis V, Sauerborn R. Potential distribution of dengue fever under scenarios of climate change and economic development. Ecohealth. 2012; 9(4):448-454. Available from: http://www.ncbi.nlm.nih.gov/pubmed/2340810 0 .

8. Harapan, Rajamoorthy Y, Anwar S, Bustamam A, Radiansyah A, Angraini P, et al. Knowledge, attitude, and practice regarding dengue virus infection among inhabitants of Aceh, Indonesia: a cross-sectional study. BMC Infectious Diseases. 2018; 18(1): 96. doi: 10.1186/s12879-018-3006-z.

9. Pratama IP, Rahayu S. Hubungan tingkat urbanisasi dengan kejadian Demam Berdarah Dengue di Kota Semarang. Universitas Diponegoro; 2015. Available from: http://eprints.undip.ac.id/62235/.

10. Satoto TBT, Pascawati NA, Wibawa T, Frutos R, Maguin S, Mulyawan IK, et al. Entomological index and home environment contribution to Dengue Hemorrhagic Fever in Mataram City Indonesia. Kesmas: National Public Health Journal. 2020; 15(1): 32-39. doi:10.21109/kesmas.v15i1.3294.

11. Riyanto A. Analisis faktor-faktor yang berhubungan dengan perilaku masyarakat dalam Pemberantasan Sarang Nyamuk Demam Berdarah Dengue (PSN-DBD) di Kelurahan Cigugur Tengah Kota Cimahi. Kesehatan Kartika; 2014. Available from: https://adoc.pub/oleh-agus-riyantoskmmkes.html.

12. Ostfeld RS, Glass GE, Keesing F. Spatial epidemiology: an emerging (or re-emerging) discipline. Trends Ecol Evol. 2005; 20(6): 328-36. doi: 10.1016/j.tree.2005.03.009.

13. Dinas Kesehatan Kota Mataram. Laporan Kasus DBD per Tahun. Mataram; 2018.

14. Nurjannah, Khotimah H, Sumiyati. Analisis ciri khas pola kehidupan sosial masyarakat Suku Donggo: Suatu tinjauan sejarah sosial budaya. Jurnal Penelitian dan Pengkajian Ilmu Pendidikan:e-Saintika. 2017; 1(1): 18-32. doi: https://doi.org/10.36312/e-saintika.v1i1.4.
15. Lemeshow S, Hosmer DW, Klar Janelle, Lwanga SK. Adequacy of Sample Size in Health Studies. England. WHO; 1990. Available from: https://apps.who.int/iris/bitstream/handle/1066 5/41607/0471925179_eng.pdf?sequence $=1$.

16. Siqueira JB, Martelli CMT, Maciel IJ, Oliveira RM, Ribeiro MG, Amorim FP, et al. Household survey of dengue infection in central Brazil: spatial point pattern analysis and risk factors assessment. Am J Trop Med Hyg. 2004; 71(5): 646-51. Available from: http://www.ncbi.nlm.nih.gov/pubmed/1556979 9.

17. Siregar FA, Abdullah MR, Omar J, Sarumpaet SM, Supriyadi T, Makmur T, et al. Social and environmental determinants of dengue infection risk in North Sumatera Province, Indonesia. Asian Journal Epidemiology. 2015; 8(2): 23-35. doi: 10.3923/aje.2015.23.35.

18. Ghozali. Analisis multivariat program. Semarang: UNDIP; 2013.

19. Sopiyudin D. Statistika untuk kedokteran dan kesehatan. Jakarta: Salemba Medika; 2017. 1$181 \mathrm{p}$.

20. Achmadi UF. Manajemen penyakit berbasis wilayah. Jakarta: Penerbit Buku Kompas; 2005. 315 p. Available from: https://www.worldcat.org/title/manajemenpenyakit-berbasis-wilayah/oclc/298348640.

21. Handoyo W, Hestiningsih R, Martini. Hubungan sosiodemografi dan lingkungan fisik dengan kejadian Demam Berdarah Dengue (DBD) pada masyarakat pesisir pantai Kota Tarakan (Studi kasus pada daerah buffer Kantor Kesehatan Pelabuhan Kelas II Tarakan). Jurnal Kesehatan Masyarakat. 2015; 3(3): 186-195. Available from: http://ejournals1.undip.ac.id/index.php/jkm.

22. Dardjito E, Yuniarno S, Wibowo C, DL Agung $S$, Dwiyanti $H$. Beberapa faktor yang berpengaruh terhadap kejadian Demam Berdarah Dengue (DBD) di Kabupaten Banyumas. Media Penelitian dan Pengembangan Kesehatan. 2008; 18(3): 126136. Available from: http://ejournal.litbang.kemkes.go.id/index.php/ MPK/article/view/1080.

23. Pongsumpun P, Patanarapelert K, Sriprom M, Varamit S, Tang I M. Infection risk to travelers going to dengue fever endemic regions. Southeast Asian J Trop Med Public Health. 
2004; 35(1): 155-9. Available from: http://www.ncbi.nlm.nih.gov/pubmed/1527276 0 .

24. Krystosik A, Njoroge G, Odhiambo L, Forsyth JE, Mutuku F, LaBeaud AD. Solid wastes provide breeding sites, burrows, and food for biological disease vectors, and urban zoonotic reservoirs: a call to action for solutions-based research. Front.Public Health. 2020; 7(405): 117. doi: 10.3389/fpubh.2019.00405.

25. Suwannapong N, Tipayamongkholgul M, Bhumiratana A, Boonshuyar C, Howteerakul N, Poolthin S. Effect of community participation on household environment to mitigate dengue transmission in Thailand. Trop Biomed. 2014; 31(1): 149-58. Available from:http://www.ncbi.nlm.nih.gov/pubmed/24 862055.

26. Wai KT, Htun PT, Oo T, Myint H, Lin Z, Kroeger A, et al. Community-centred eco-biosocial approach to control dengue vectors: An intervention study from Myanmar. Pathog Glob Health. 2012; 106(8): 461-8. doi: $10.1179 / 2047773212$ Y.0000000057.

27. Koenraadt CJM, Tuiten W, Sithiprasasna R, Kijchalao U, Jones JW, Scott TW. Dengue knowledge and practices and their impact on Aedes aegypti populations in Kamphaeng Phet, Thailand. Am J Trop Med Hyg. 2006; 74(4): 692-700.

https://doi.org/10.4269/ajtmh.2006.74.692.

28. Boornema AR, Senthil MTK. Breeding habitats of Aedes aegypti mosquitoes and awareness about prevention of dengue in urban Chidambaram: a cross sectional study. Int J Community Med Public Heal. 2018; 5(10): 4584-89. doi: http://dx.doi.org/10.18203/23946040.ijcmph20184014.

29. Nguyen HV, Than PQT, Nguyen TH, Vu GT, Hoang CL, Tran TT, et al. Knowledge, attitude and practice about dengue fever among patients experiencing the 2017 outbreak in Vietnam. Int J Environ Res Public Health. 2019; 16(6): $976 . \quad$ doi: 10.3390/ijerph16060976.

30. Wong LP, Shakir SMM, Atefi N, AbuBakar S. Factors affecting dengue prevention practices: nationwide survey of the Malaysian public. PLoS One. 2015; 10(4): e0122890. doi: 10.1371/journal.pone.0122890.
31. Zahir A, Ullah A, Shah M, Mussawar A. Community participation, dengue fever prevention and control in Swat, Pakistan. Int $\mathbf{J}$ MCH AIDS. 2016; 5(1): 39-45. doi: 10.21106/ijma.68.

32. Waite JL, Swain S, Lynch PA, Sharma SK, Haque MA, Montgomery J, et al. Increasing the potential for malaria elimination by targeting zoophilic vectors. Sci Rep. 2017; 7:40551. doi: 10.1038/srep40551.

33. Franco AO, Gomes MGM, Rowland M, Coleman PG, Davies CR. Controlling malaria using livestock-based interventions: a one health approach. Plos One. 2014; 9(7): e101699. https://doi.org/10.1371/journal.pone.0101699.

34. Hasyim H, Dhimal M, Bauer J, Montag D, Groneberg DA, Kuch U, et al. Does livestock protect from malaria or facilitate malaria prevalence? a cross-sectional study in endemic rural areas of Indonesia. Malaria Journal. 2018; 17(302):1-11. https://doi.org/10.1186/s12936018-2447-6.

35. Pratamawati DA, Irawan AS, Widiarti. Hubungan antara perilaku penggunaan insektisida rumah tangga dengan riwayat pernah sakit Demam Berdarah Dengue di Provinsi Bali Tahun 2011. Spirakel. 2017; 7(2): 15-27. doi: 10.22435/spirakel.v7i2.6130.15-27.

36. Satoto TBT, Dwiputro AH, Risdwiyanto RN, Hakim AUF, Pascawati NA, Diptyanusa A. Prediction model of dengue hemorrhagic fever transmission to enhance early warning system in Gergunung Village Klaten District Central Java. Journal of the Medical Science. 2019; 51(3):

258-269. https://doi.org/10.19106/JMedSci00510320190 9.

37. Kusumastuti NH. Penggunaan insektisida rumah tangga antinyamuk di Desa Pangandaran Kabupaten Pangandaran. Widyariset. 2014; 17(3): 417-24. Available from:http://widyariset.pusbindiklat.lipi.go.id/in dex.php/widyariset/article/viewFile/286/274.

38. Bellinato DF, Viana-Medeiros PF, Araújo SC, Martins AJ, Lima JBP, Valle D. Resistance status to the insecticides temephos, deltamethrin, and diflubenzuron in Brazilian Aedes aegypti populations. Biomed Res Int. 2016; 2016:8603263. $10.1155 / 2016 / 8603263$. 